\title{
Bragantia: um novo ciclo
}

Bragantia iniciou suas publicações em 1941 com a missão de publicar textos inéditos que contribuam para com o avanço científico e tecnológico das ciências agrárias. Sendo atualmente um dos mais tradicionais e respeitados periódicos brasileiros, esse veículo de comunicação científica passou por diversas transformaçôes ao longo de sua história. A partir de 1953 adotou o sistema ininterrupto de suas publicações. Após 1992 passou a publicar trabalhos oriundos de outras instituiçóes e a contar com editores associados pertencentes a renomados e distintos centros brasileiros de ensino e pesquisa. Em 2009 adotou o sistema eletrônico de submissão de manuscritos via portal SciELO. A partir do primeiro fascículo do volume 72 , a revista científica Bragantia passará a adotar apenas a versão eletrônica em suas publicações. Essa ação vem ao encontro da tendência mundial, na qual a difusão do conhecimento é rápida e com economia de recursos.

Indexada em importantes bases de dados como SciELO, Scopus, Redalyc e ISI Web of Science, Bragantia apresenta um tempo médio de avaliação dos manuscritos de 87 dias entre a submissão do arquivo original e a emissão do parecer final. As metas para o triênio 2013-2015 são o constante aprimoramento do processo editorial, que visa primordialmente manter a alta qualidade dos textos publicados com a rapidez desejável para a divulgação dos estudos. Evidentemente, as ações afetarão diretamente o fator de impacto da Bragantia. Para o maior alcance da informação, o Comitê Editorial incentivará a utilização da língua inglesa nos textos científicos. Nos próximos meses, haverá também a migração para um novo sistema de gerenciamento eletrônico das submissôes, o Scholarone.

Por fim, o Comitê Editorial de Bragantia agradece o papel fundamental de todos os editores e revisores que, por mais de 70 anos, participam da história de nossa revista. Há também um agradecimento especial aos autores e seus artigos que são nosso maior patrimônio.

Cordialmente,

Gabriel Constantino Blain

Editor-chefe | Bragantia

Rafael Vasconcelos Ribeiro

Editor-assistente | Bragantia 